\title{
Genetic material of producers of cattle of Volynsk meat breed in bank of genetic resources of animals of M. Zubets Institute of animal husbandry and animal genetics of NAAS
}

\author{
B. Podoba, \\ doctor of agricultural sciences \\ P. Dzhus, \\ candidate of Biological sciences \\ O. Sydorenko, M. Dobrianska, L. Vishnevskiy \\ candidates of agricultural sciences \\ N. Kuzebna \\ Institute of Animals Breeding and Genetics nd. a. M.V.Zubets of NAAS \\ T. Yanko, \\ Investment company «Meat Invest» \\ K. Kopylova, \\ doctor of agricultural sciences \\ Institute of food resources of NAAS
}

The purpose. Immunogenetic and molecular analysises of sperm of bulls of Volynsk meat breed which is stored in bank of genetic resources of animals of M. Zubets Institute of animal husbandry and animal genetics of NAAS. Methods. Determination of blood groups of producers by erythrocyte antigens of 9 systems (A, B, C, F, I, L, M, S, Z) and alleles of system B. Polymorphy of locuses CAPN 1530 and TG 5 of genes of kalpain and thyreoglobulin was determined using polymerase-chain reaction with the subsequent electrophoretic separation of restricting fragments of DNA in agarose gel. Results. Individual immunogenetic and molecular analysises were carried out of13 bulls of Volynsk meat breed which biological material was included for long-term storage. Rare for cattle carrying agents of antigen of $M$ were fixed. Frequency of desirable allele $G$ of gene of kalpain at probed animals made 0,654 , of desirable allele $T$ of gene of thyreoglobulin - 0,269. Conclusions. Obtained data will enable to forecast driving the genetic information in generations of offsets of probed producers.

Key words: Volynsk meat breed, genetic material, blood groups, genes of kalpain and thyreoglobulin.

Problem. The rapid development of genetic methods led to the intensification of their use in breeding work with different breeds of cattle, including beef direction and performance. The beginning of the use of genetic markers in livestock research Volynian beef breed were 80 years of last century, when tested first local animals obtained from industrial crossbreeding of local Black and White and Red Polish cattle with bulls of specialized beef breeds: Aberdyn-Angus, Hereford and Limousine [1].

Systematic examination immunogenetic of breeding animals carried out in a laboratory genetic basis of breeding of Institute of Animal Breeding and Genetics UAAS and Republican immunogenetics laboratory (c. Brovary). Testing blood groups conducted pursuant to the general requirements for the control of origin as a mandatory element breeding to ensure the reliability of the newly established national pedigree animals of cattle of beef breed. Accumulated individual information used for the comprehensive analysis of immunogenetic structure of breed [2].

Pursuant to the conservation programs of genetic diversity of farm animals along with biological material laying on points of Representatives rocks to long-term storage it provides for identifying different types of marker systems. Thus, the aim of the presented research was immunogenetic and molecular analysis sperm of bulls of Volynian beef breed that is kept in the bank of animals of genetic resources of IABG nd. a. M.V.Zubets of NAAS.

Materials and methods. For using research used of biological material of bulls of Volynian beef breed, which is involved in the formation of the DNA bank. Immune-genetic evaluation conducted taking into account the types of blood erythrocyte antigen 9 systems (A, B, C, F, I, L, M, S, Z) and of alleles system [3, 4].

Identification bulls of loci genotype for CAPN 1530 and TG 5 calpain and thyroglobulin gene carried by molecular genetic analysis of PCR-RFLP. Genomic DNA was isolated using the reagent "Chelex-100"; and 
using a standard set of commercial "DNA Sorb B" (AmpliSens, Russia), according to manufacturer's recommendations. Temperature and number of cycles of PCR amplification for each gene were identified separately. Amplification fragments studied genes was performed using appropriate primers [5].

Results. At the bank of Institute in storage is 6232 sperm doses from 13 bulls of Volynian beef breed, which representing uncommon lines of Buynoho 3042, Tsebryka 3888, Yamba 3066 and Krasavchyka 3004 and Sonnoho 3307-Kaktusa 9828 (table. 1). The spectrum of erythrocyte antigens they observed a variety: identified carriers relatively rare in cattle antigen M (sire Bober 2477) (table 2). For EAS system available genetic material antigens $\mathrm{U}, \mathrm{U}^{\prime}, \mathrm{H}^{\prime \prime}, \mathrm{U}^{\prime \prime}$, the system EAC observed moderate variability factors of blood groups.

For systems alleles observed EAV overwhelming number of bulls with markers Aberdeen-Angus breed. In particular, in line Buynoho 3042 (allele $Y Y^{\prime}$ ), allele ${ }_{1}{ }_{1}{ }^{\prime} E^{\prime} Y^{\prime}$ found in animals of lines Tsebryka 3888, Buynoho 3042. Allele of Limousin breed BGKE'G'O'G" marked line Yamba 3066, $I_{1} Y^{\prime} E^{\prime} Y^{\prime}$ - is in bulls of lines Tsebryka 3888, Buynoho 3042.

1. Genealogical characteristic bulls of Volynian beef breed, semen of which is stored in a the of bank of genetic resources of animals of IABG nd. a. M.V.Zubets of NAAS

\begin{tabular}{|c|c|c|c|c|c|}
\hline \multirow[b]{2}{*}{$\begin{array}{c}\text { Name of animal, } \\
\text { ind. № }\end{array}$} & \multicolumn{3}{|c|}{ Father } & \multicolumn{2}{|r|}{ Mother } \\
\hline & $\begin{array}{l}\text { Name of } \\
\text { animal, } \\
\text { ind. № }\end{array}$ & Genotype & Line & $\begin{array}{l}\text { Name of } \\
\text { animal, } \\
\text { ind. № }\end{array}$ & Genotype \\
\hline Bober 2477 & Badan 827 & LI 3/8 AA HE 1/8 BW & $\begin{array}{l}\text { Buynoho } \\
3042\end{array}$ & $\begin{array}{l}\text { Ternynka } \\
2137\end{array}$ & LI HE BW \\
\hline Bobryk 2352 & Badan 827 & LI $3 / 8$ AA HE $1 / 8$ BW & $\begin{array}{l}\text { Buynoho } \\
3042\end{array}$ & $\begin{array}{l}\text { Soroka } \\
2087\end{array}$ & LI AA BW \\
\hline Berest 670 & Bas 2404 & LI 7/16 AA 3/16 HE 1/8 BW & $\begin{array}{l}\text { Buynoho } \\
3042\end{array}$ & $\begin{array}{l}\text { Lasunka } \\
539\end{array}$ & LI AA 1/8 HE 1/8 BW \\
\hline Tsvit 658 & $\begin{array}{l}\text { Tsnot } \\
2307\end{array}$ & LI AA 1/8 HE 1/8 BW & $\begin{array}{l}\text { Tsebryka } \\
3888\end{array}$ & Layka 923 & LI 3/8 AA 5/16 BW 5/16 \\
\hline 'Tsyrkul' 614 & $\begin{array}{l}\text { Tsnot } \\
2307\end{array}$ & LI AA 1/8 HE 1/8 BW & $\begin{array}{l}\text { Tsebryka } \\
3888\end{array}$ & $\begin{array}{l}\text { Bakaliya } \\
1330\end{array}$ & LI AA 1/8 HE 1/8 BW \\
\hline Baltiyets' 964 & $\begin{array}{l}\text { Zond } \\
57754\end{array}$ & LI AA1/8 HE 1/8 BW & $\begin{array}{l}\text { Tsebryka } \\
3888\end{array}$ & $\begin{array}{l}\text { Borul'ka } \\
439\end{array}$ & LI HE BW \\
\hline Yakut 2398 & $\begin{array}{l}\text { Yamal } \\
1139\end{array}$ & LI AA 3/16 HE 1/16 BW & Yamba 3066 & Myrna 212 & LI AA1/8 HE 1/8 BW \\
\hline Yavir 2391 & $\begin{array}{l}\text { Yamal } \\
1139\end{array}$ & LI AA 3/16 HE 1/16 BW & Yamba 3066 & $\begin{array}{l}\text { Sunytsya } \\
443\end{array}$ & LI AA BW \\
\hline Charodiy 805 & $\begin{array}{l}\text { Yamb } \\
3066\end{array}$ & LI HE BW & Yamba 3066 & Chaplya 71 & LI AA BW \\
\hline Kaktus 2491 & Kubok 358 & LI 3/8 AA HE 1/8 4 & $\begin{array}{l}\text { Krasavchyka } \\
3004\end{array}$ & $\begin{array}{l}\text { Holubka } \\
481\end{array}$ & LI AA BW \\
\hline Kovryk 2430 & Kubok 358 & LI 3/8 AA HE 1/8 BW & $\begin{array}{l}\text { Krasavchyka } \\
3004\end{array}$ & $\begin{array}{l}\text { Lyal'ka } \\
3844\end{array}$ & LI AA HE BW \\
\hline Klen 2493 & Kubok 358 & LI 3/8 AA HE 1/8 BW & $\begin{array}{l}\text { Krasavchyka } \\
3004\end{array}$ & $\begin{array}{l}\text { Charka } \\
1065\end{array}$ & LI HE BW \\
\hline Tsyhan 893 & $\begin{array}{l}\text { Kaktus } \\
9828\end{array}$ & LI AA 5/16 HE BW 1/16 & $\begin{array}{l}\text { Sonnoho } \\
3307-K a k t u s a \\
9828\end{array}$ & $\begin{array}{l}\text { Tsytra } \\
1546\end{array}$ & LI AA 1/8 HE 1/8 BW \\
\hline
\end{tabular}

Note. Breeding of animals: LI - limousine, HE - Hereford, AA-Aberdeen-Angus, BW - Black-and-White . 
Although of genetic material a range of lines submitted by halfsibs of some bulls, but the immunogenetic markers are quite different. In particular in line of Krasavchyka 3004 it are sons Kubka 358, but namely in they to present markers of Hereford breed - alleles $\mathrm{B}^{\mathrm{YD} \mathrm{DI}^{\prime}}$ and $\mathrm{BA}^{\prime} \mathrm{O}^{\prime}$. In genotype of bulls found some alleles of Black and White and Red Polish of cattle: VRQI', BQE'F'I'Q', OG'J'K'O'G".

2. Types of blood bulls of Volynian beef breed, semen of which is stored in the of bank of animals of genetic resources of IABG nd. a. M.V.Zubets of NAAS

\begin{tabular}{|c|c|c|c|c|c|c|c|c|c|}
\hline \multirow{2}{*}{$\begin{array}{l}\text { Name of } \\
\text { animal, } \\
\text { ind. № }\end{array}$} & \multicolumn{9}{|c|}{ Genetic blood group system } \\
\hline & A & B & C & $\mathbf{F}$ & $\mathbf{J}$ & $\mathbf{L}$ & $\mathbf{M}$ & $\mathbf{S}$ & $\mathbf{Z}$ \\
\hline Bober 2477 & $\mathrm{~A}$ & YY /BGKYO & $\mathrm{K}_{2} \mathrm{~W}$ & $\mathrm{~F}$ & & $\mathrm{~L}$ & $\mathrm{M}$ & $\mathrm{HU}$ & Z \\
\hline Bobryk 2352 & A & $Y Y / I_{1} Y E Y$ & W & FV & $\mathrm{J}$ & $\mathrm{L}$ & $\mathrm{M}$ & $\mathrm{H}$ & $Z$ \\
\hline Berest 670 & $A$ & $\mathrm{G}_{3} \mathrm{OTY} / \mathrm{YD} \mathrm{E}$ & W & $\mathrm{F}$ & & & & $\mathrm{UHH} \mathrm{U}$ & Z \\
\hline Buynyy 3042 & A & BGKE G O G $/ Y Y$ & $\mathrm{P}_{2} \mathrm{~W}$ & $\mathrm{~F}$ & & & & $\mathrm{SUHHU}$ & Z \\
\hline Tsvit 658 & A & $\mathrm{I}_{1} \mathrm{YE} \mathrm{Y} / \mathrm{OG} \mathrm{J} \mathrm{K} \mathrm{O} \mathrm{G}$ & CEWX ${ }_{2}$ & $\mathrm{~F}$ & & $\mathrm{~L}$ & & $\mathrm{U}$ & Z \\
\hline Tsyrkul' 614 & & GYA G G /GTYA G & CEW & $\mathrm{F}$ & & $\mathrm{L}$ & & $\mathrm{HU}$ & Z \\
\hline Baltiyets'964 & & $1, Y E Y / G$ & & & & & & & \\
\hline Tsebryk 3888 & & GYA G G $/ /_{1} Y E Y$ & $\mathrm{CER}_{1} \mathrm{~W}$ & $\mathrm{~F}$ & & & & $\mathrm{H}$ & Z \\
\hline Charodiy 805 & & YE G Q Y /BPQI & CEW & FV & & $\overline{\mathrm{L}}$ & & $\mathrm{H}$ & \\
\hline Yakut 2398 & A & $\mathrm{G}_{3} \mathrm{OTK} / \mathrm{YD} \mathrm{E} \mathrm{O}$ & $\mathrm{CER}_{1} \mathrm{WX}_{1}$ & $\mathrm{~F}$ & & & & $\mathrm{H}$ & Z \\
\hline Yavir 2391 & A & BGKE G O G $/ \mathrm{G}_{3} \mathrm{OTK}$ & $\mathrm{CR}_{1} \mathrm{WX}_{2}$ & $\mathrm{~F}$ & $\mathrm{~J}$ & $\mathrm{~L}$ & & $\mathrm{HU}$ & $Z$ \\
\hline Yamb 3066 & $A$ & BGKE G O G /A O & $\mathrm{CWX}_{1}$ & $\mathrm{~F}$ & $\mathrm{~J}$ & $\mathrm{~L}$ & & SU & $Z$ \\
\hline Kaktus 2491 & A & $\mathrm{G}_{3} \mathrm{OTK} / \mathrm{YD} \mathrm{I}$ & $\mathrm{CER}_{2} \mathrm{~W}$ & $\mathrm{~F}$ & $\mathrm{~J}$ & $\mathrm{~L}$ & $\mathrm{M}$ & $\mathrm{UHHU}$ & \\
\hline Kovryk 2430 & A & OTYE K G /GA D E F G O G & $\mathrm{CER}_{2} \mathrm{WX}_{2}$ & $\mathrm{~F}$ & & $\mathrm{~L}$ & & $\mathrm{H}$ & \\
\hline Klen 2493 & A & A O /BQE F I Q & $\mathrm{CER}_{2} \mathrm{X}_{2}$ & $\mathrm{FV}$ & & $\mathrm{L}$ & & $\mathrm{HU}$ & \\
\hline $\begin{array}{l}\text { Krasavchyk } \\
3004\end{array}$ & A & OTYE K G / G ${ }_{3}$ OTK & $\mathrm{C}_{1} \mathrm{EWX}_{1}$ & $\mathrm{~F}$ & & & & $\mathrm{SUH} \cup \mathrm{H}_{1} \mathrm{U}$ & Z \\
\hline Tsyhan 893 & & $\mathrm{G}_{3} \mathrm{OTK} / \mathrm{G}$ & W & $\mathrm{F}$ & & $\mathrm{L}$ & & $\mathrm{HU}$ & \\
\hline
\end{tabular}

By increasing relevance conducting purposeful selection as one of the essential measures to preserve the genetic diversity of farm animals becomes effective instruments in life typing loci of quantitative traits, mutations which allow the use of molecular markers to establish the genotype of animals by the studied gene. World experience of countries with developed livestock confirms that in assessing the quality of beef cattle emphasis should be made on beef tenderness and marbling that relate to quality, genetically determined traits productivity of cattle $[6,7,8]$.

For locus gene CAPN1530 calpain that associated with beef tenderness, is the most polymorphic line Yamba 3066. Representatives this line turned out carriers of the three possible genotypes studied gene (table. 3). Similar in genetic structure turned out lines Buynogo 3042 and Krasavchyka 3004. Homozygous carriers of desired alleles $\mathrm{G}$ is bulls Bober 2477, Berest 670, Kovryk 2430, Klen 2493 and Charodiy 803 and frequency $G$ allele was 0.654 . Of the 13 sires only Tsvit 658 and Yakut 2398 had genotype AA. Other bulls were heterozygous $A G$ and their share was 0.385 .

3. Genotype bulls for markers CAPN1530 and TG5 calpain and thyroglobulin genes

\begin{tabular}{|c|c|c|}
\hline \multirow{2}{*}{ Name of animal, ind. № } & \multicolumn{2}{|c|}{ locus } \\
\hline & CAPN1530 & TG5 \\
\hline \multicolumn{3}{|l|}{ line Buynogo 3042} \\
\hline Bober 2477 & GG & CC \\
\hline Bobryk 2352 & $A G$ & $\mathrm{CC}$ \\
\hline Berest 670 & GG & TT \\
\hline \multicolumn{3}{|l|}{ line Tsebryka 3888} \\
\hline Tsvit 658 & AA & CC \\
\hline Tsyrkul' 614 & $A G$ & $\mathrm{CC}$ \\
\hline line Krasavchyka 3004 & & \\
\hline
\end{tabular}




\begin{tabular}{|l|c|c|}
\hline $\begin{array}{l}\text { Kovryk 2430 } \\
\text { Klen 2493 }\end{array}$ & GG & CT \\
Kaktus 2491 & GG \\
& AG \\
\hline \multicolumn{1}{|c|}{ line Yamba 3066 } & & \\
\hline Yavir 2391 AG & CC \\
Yakut 2392 & AA \\
Charodiy 803 & GG & CC \\
\hline \multicolumn{1}{|c|}{ line Sonnoho 3307-Kaktusa 9828 } & AG & CC \\
\hline Tsyhan 893 & & \\
\hline
\end{tabular}

According to the results of typing TG5 gene locus polymorphic thyroglobulin most line Krasavchyka 3004. Lines Buynogo 3042 and Yamba 3066 alike the distribution of genotypes in lines Tsebryka 3888 and Sonnoho 3307-Kaktusa 9828 heterozygous bulls absent. For gene thyroglobulin bulls Berest 670 and Cactus 2491 - homozygous for the T allele desirable and potentially valuable bulls for distribution of alleles in domestic livestock. In general allele frequencies were 0.269 and 0.731 .

\section{Conclusions.}

Thus, in the results of immunogenetic and molecular genetic studies determined the individual characteristics of bulls Volynian beef breed for systems of blood group and polymorphism QTL-loci involved in the determination of quality indicators of beef. The resulting information will predict the future movement of genetic information in offspring generations studied bulls that are currently involved in the formation of basic livestock breeding farms array Volynian region.

\section{Bibliography}

1. Yanko, T. S. Podoba, B. Ye., Tsiluyko, H. O. (2005). Henetychna struktura y rozvytok zavods'kykh liniy Volynians'koyi myasnoyi porody (do pytannya «korotkykh liniy»). Derzhavna knyha pleminnykh tvaryn velykoyi rohatoyi khudoby Volynians'koyi m"yasnoyi porody. Kyyiv , Vydavnychyy dim «Stylos», 68-75.

2. Zubets M. V., Burkat V. P., Melnyk lu. F. [ta in.]. (2000). Henetyko-selektsiinyi monitorynh u miasnomu skotarstvi. K. : Ahrarna nauka, 187.

3. Podoba, B. Ye., Kopylova, K. V., Podoba, Yu. V. [ta in.] (2011). Pleminnyy material Volynians'koyi m"yasnoyi porody $v$ banku henetychnykh resursiv tvaryn IRHT. Visn. ahrar. nauky: nauk.teoret. zhurn, 12: 36-39.

4. Tsiluyko H. O., and Zabludovskyy Ye. Ye. 2000. Metodychni rekomendatsiyi po zastosuvannyu henetychnykh markeriv $v$ selektsiyi myasnoyi khudoby. Kyiv, Naukovyy svit, 20.

5. Burkat, V. P., Didyk, M. V., Podoba, B. Ye (1996). Imunohenetychni doslidzhennya v zavods'kykh stadakh velykoyi rohatoyi khudoby. Novi metody selektsiyi $i$ vidtvorennya vysokoproduktyvnykh porid $i$ typiv tvaryn. K., Asotsiatsiya «Ukrayina», 31.

6. Zubets', M. V. Tsiluyko, H. O., Lukash, V. P. (1996). Henetychni markery v selektsiyi $i$ vidtvorennya vysokoproduktyvnykh porid i typiv tvaryn. K., Asotsiatsiya «Ukrayina». - $76 \mathrm{~s}$.

7. Ruban, S. Yu., Huzyev, I. V., Kopylov, K. V. [ta in.] (2010). Instruktsiya henomnoho typuvannya $v$ molochnomu, molochno-m"yasnomu ta m"yasnomu skotarstvi dlya provedennya henetychnykh doslidzhen' za DNK - markeramy. NAAN Ukrayiny, Instytut rozvedennya i henetyky tvaryn. - Chubyns'ke, $-29 \mathrm{~s}$.

8. Casas E., White, S. N., Riley, D. G., Smith, T. P. L., Brenneman, R. A., Olson, T. A., Johnson, D. D., Coleman, S. W., Bennett, G. L., Chase, C. C. (2005). Assessment of single nucleotide polymorphisms in genes residing on chromosomes 14 and 29 for association with carcass composition traits in Bos indicus cattle. J. Anim. Sci. 83:13-19.

9. Barendse, W. J., Bunch, R., Thomas, M. Armitage, S., Baud, S., Donaldson, N. (2004). The TG5 thyroglobulin gene test for a marbling quantitative trait loci evaluated in feedlot cattle Austr. J. Exp. Agricult. 44:66.

10. Page, B. T., Casas, E., Heaton, M. P. Cullen, N. G., Hyndman, D. L., Morris, C. A., Crawford, A. M., Wheeler, T. L., Koohmaraie, M., Keele, J. W., Smith, T. P. L. (2002). Evaluation of single-nucleotide polymorphisms in CAPN1 for association with beef tenderness in cattle. J. Anim. Sci. 80:3077-3085. 